\title{
A Rare Cause of Acute Ischemic Stroke: Herbal Chocolate
}

(10) Ayla Köksal', Cesareddin Dikmetaş', Serkan Doğan', Ahmet Erdur

'Department of Emergency Medicine, Istanbul Health Sciences University Kanuni Sultan Süleyman Training and Research Hospital

\begin{abstract}
The frequency of use of many food supplements sold under the name of herbal products has increased today. As a result of easy access to the whole society with tools such as television, radio and especially the internet, many such products sold uncontrolled and outside the control of physicians can cause serious health problems. Our case reports a 65 -year-old male patient who was admitted to the emergency service with a headache and left arm numbness. In the detailed history taken, it was learned that he used a herbal product without the recommendation and control of the physician in order to increase sexual power. It was learned that he did not have any known disease, operation, and medicine used under the control of a physician. It is known that such herbal products cause serious neurological events. The use of these products should be questioned, especially in patients who are admitted to the emergency department with acute neurological complaints and have no apparent medical history.

Keywords: chocolate, herbal product,stroke.
\end{abstract}

\section{Introduction}

Today, the use of herbal products has increased all over the world. Many people can easily obtain these products from various stores that are not audited with tools that facilitate access and promotion to all segments of the society such as television, radio and especially the internet. In promotions made through all means, these products may cause a false perception that these products are natural and harmless. There is no detailed research on the actual ingredients, active metabolites and side effects of these products. Phytochemicals included in the composition of the products can affect especially the fibrinolytic system with its pharmacokinetic and pharmacodynamic mechanism. As a result, unwanted coagulation and bleeding disorders may occur in people who use $\mathrm{it}^{1-3}$.

Sexual dysfunctions are among the most common problems worldwide. Many studies in the literature reveal that, regardless of gender, at least one out of every 3 people experience at least one sexual dysfunction in any period of their lives $^{4}$. Reduced sexual desire, orgasm disorder and vaginismus in women, erectile dysfunction in men, premature ejaculation and lack of sexual desire are among the most common problems ${ }^{5,6}$.

Psychological problems that can lead to loss of self-confidence, decrease in quality of life and even depression can be seen frequently in individuals with sexual dysfunction?
The frequency of referral to physicians with sexual disorders is low, especially due to cultural and social factors. For this reason, these herbal products, which are presented as advertising products and are easy to access, are tried to be solved in secret, and the unconscious use of these products causes serious events ${ }^{8}$. In this case report, we wanted to talk about the ischemic stroke patient that occurred after the herbal product used to increase sexual performance and his management in the emergency room.

\section{Case Report}

A 65-year-old male patient was admitted to the emergency department with complaints of neck pain and left arm numbness in the last 2 hours after a headache that persisted for 2 days. The patient's history was unremarkable. The patient was in good general condition, conscious and cooperatively oriented, and the blood pressure arteriole was 190/100 mmHg and other vital signs were stable. The patient's neurological examination revealed hemihypoesthesia in the left upper extremity and hypoactivity in the deep tendon reflexes. The patient was taken to the emergency department critical examination area and radiological imaging and laboratory tests were requested. In the cranial computed tomography of the patient, hypodense area in the right parietooccipital region, hyperintensity in the right parietooccipi- 


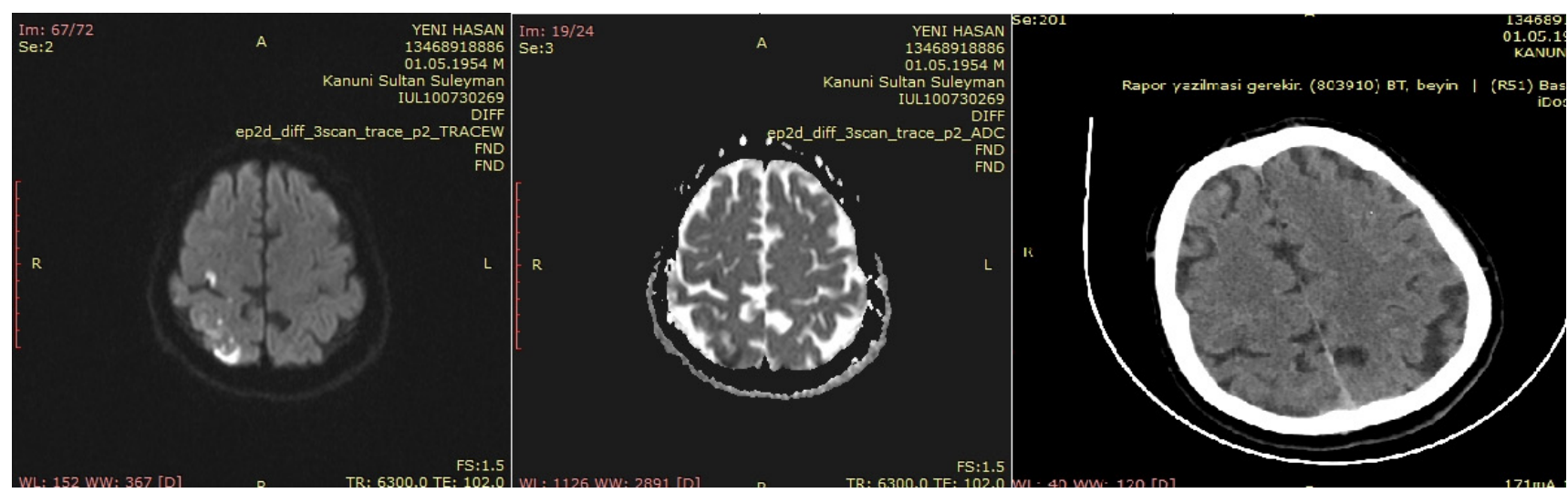

Picture 1: Brain Tomography and MR image of the patient

tal region in diffusion-weighted cranial magnetic resonance imaging, and hypointense appearance in the diffusion coefficient map of the same region (Picture 1).

Except for the patient's high blood sugar $(287 \mathrm{mg} / \mathrm{dl})$, no obvious pathology was found. There was no pathology in the electrocardiogram of the patient. Ischemic stroke was considered in the patient. Anticoagulant therapy, antiaggregant and antihypertensive therapy were initiated in the patient, who was consulted with neurology. It was learned that the patient, who had no problem in his history, had used a product containing cocoa butter, ginseng, cocoa powder, cinnamon, lechithin, sesame, hazelnut, and vanilla flavoring 3-5 times a day for the last 3 days when his history of stroke was deepened. It was learned that he last took it before going to bed at night. It was learned that this product used by the patient was a herbal product and was used to increase sexual performance. The patient was admitted to the neurology service for follow-up and treatment. It was learned that she was discharged after neurology follow-ups, after being advised to come to the polyclinic controls.

\section{Discussion}

Sexual dysfunctions are very common in society. One in three men experiences sexual dysfunction at least in their life. However, treatment is less under the control of a physician. Among the sexual dysfunctions, sexual anorexia, erectile dysfunction are the most common and the third most common sexual dysfunction ${ }^{9}$.

Premature ejaculation is a common disorder at a rate of $20-30 \%{ }^{10}$. Psychological and medical therapy should be combined in treatment. The medical treatment uses topical creams, selective serotonin reuptake inhibitors (SSRI), phosphodiesterase 5 (PDE-5) and tramadol ${ }^{10,11}$. Due to cultural and social factors, solutions for treatment are sought without consulting a physician. For this reason, products claimed to be harmless herbal products are preferred in easy-to-reach internet, television and similar media.
The drugs used in medical treatment are approved for use in the market after passing many tests. Side effects and possible drug interactions of herbal products are not routinely carried out. In our country, licensing and various regulations are carried out by the ministry of health and the ministry of agriculture and food in herbal products. Nevertheless, it is known that after licensing, some manufacturers can apply methods in which various chemical substances are added to increase production efficiency. The active substance sildenafil was detected in the product used by our patient, and this substance was included in the banned products list in $2019^{12}$.

Cerebrovascular diseases (CVD), defined as stroke, are among the leading diseases that cause serious mortality and morbidity. Ischemic strokes constitute $80-85 \%$ of $\mathrm{SVH}^{10}$. When etiological risk factors are examined, unchangeable (age, gender, race, genetic) and changeable risk factors (hypertension, diabetes mellitus, heart diseases, atrial fibrillation, hyperlipidemia, etc.) can be detected. Except that our patient is 65 years old and male, any cardiac, metabolic, genetic, etc. There was no risk factor.

Although there are many risk factors in the etiology of ischemic stroke, these common causes may not be common in some patients. In such cases, it should be questioned whether there is any medicine or a herbal product used by the patients. As in our patient, herbal products can be used, especially with unknown and prohibited substances. With the use of these products, our patients can apply to hospitals with neurological problems as in the example.

As a result, we can say that questioning herbal products that can be used unconsciously for various purposes in patients with acute neurological complaints, apart from major risk factors, is of great importance in terms of rapid diagnosis and treatment of patients.

\section{References}

1. Ernst E,Pitler MH.Risks associated with herbal medicinal products. Wien Med Wochenschr 2002;152:183-189. 
2. Gianni LM, Dreitlein WB. Some popular OTC herbals can interact with anticoagulant therapy. US Pharmacist 1998;23:80-86

3. Bush TM, Rayburn KS, HollowaySW, et al. Adverse interactions between herbal and dietary substances and prescription medications: aclinicalsurvey. Altem Ther Health Med2007 ;13:30-35.

4. Incesu C. Cinsel işlev ler ve cinsel işlev bozuklukları . Klinik Psikiyatri Dergisi 2004; 7(Ek3): 3-13.

5. Mert DG, Özen NE. Genel psikiatri polikliniğine başvuran kadın hastalarda cinsel işlev bozukluğu ve ilişkili sosyokültürel parametrelerin değerlendirilmesi. Klinik Psikiyatri Derg 2011;14.85-93.

6. Hariri AG,Karadağ F, Gurol DT, Aksoy UM, Texcan AE. Sexual problems in a sample of Turkish psychiatric population.Compr Psychiatry 2009;50:353-360.

7. Kennedy SH, Rizvi S (2009). Sexual dysfunction, depression, and the impackt of anti depressants. J Clin Psychopharmarcol, 29:157-164.

8. Uzun MB, Aykaç G, Özçelikay G, Bitkisel ürünlerin yanlış kullanımı ve zararları. Lokman Hekim Journal, 2014;4(3):1-5.

9. Incesu $C$. Cinsel işlev ve cinsel işlev bozuklukları. Klinik Psikiyatri Derg 2004;7:3-13.

10. Hatzimouratidis K, Amar E, Eardley I, et al. Guidelines on male sexual dysfunction: erectile dysfunction and prematüre ejaculation. Eur Urol 2010;57:804-814.

11. Waldinger MD, Zwinderman AH, Schweitzer DH, Olivier B. Relevance of methodologicaldesingfort he interpretation of efficacy of drugtreatment of prematüre ejaculation : a systematic review and meta -analysis . Int J ImpotRes 2004;16:369-381.

12.Tarım Orman Bakanlığı Gıda ve Kontrol Genel Müdürlüğü internet sitesi taklit,tağşiş, ilaç etken maddesi ilavesi duyuruları 12.10.2019 duyurusu, Erişim: https://www.tarimorman.gov.tr/GKGM/Duyuru/411/ kamuoyuna duyurulur bağlantsı son erişim :15.10.2019

13.Weinberger J. Stroke. 2, Pennsylvania ;Handbooks in HealthCare Co.,2002. 